\title{
Actions of NPY, and Its Y1 and Y2 Receptors on Pulsatile Growth Hormone Secretion during the Fed and Fasted State
}

\author{
Lili Huang, ${ }^{1}$ Hwee Y. Tan, ${ }^{1}$ Matthew J. Fogarty, ${ }^{1}$ Zane B. Andrews, ${ }^{2}$ Johannes D. Veldhuis, ${ }^{3}$ Herbert Herzog, ${ }^{4}$ \\ Frederik J. Steyn, ${ }^{1}$ and Chen Chen ${ }^{1}$ \\ ${ }^{1}$ School of Biomedical Sciences, University of Queensland, St. Lucia, Brisbane, Queensland, 4072 Australia, 2 Department of Physiology, Monash University, \\ Clayton, Victoria, 3183 Australia, ${ }^{3}$ Department of Medicine, Endocrine Research Unit, Mayo School of Graduate Medical Education, Clinical Translational \\ Science Center, Mayo Clinic, Rochester, Minnesota 55905, and ${ }^{4}$ Neuroscience Research Program, Garvan Institute of Medical Research, St. Vincent's \\ Hospital, Darlinghurst, Sydney, New South Wales, 2010 Australia
}

The hypothalamic NPY system plays an important role in regulating food intake and energy expenditure. Different biological actions of NPY are assigned to NPY receptor subtypes. Recent studies demonstrated a close relationship between food intake and growth hormone (GH) secretion; however, the mechanism through which endogenous NPY modulates GH release remains unknown. Moreover, conclusive evidence demonstrating a role for NPY and Y-receptors in regulating the endogenous pulsatile release of GH does not exist. We used genetically modified mice (germline $N p y, Y 1$, and $Y 2$ receptor knock-out mice) to assess pulsatile GH secretion under both fed and fasting conditions. Deletion of NPY did not impact fed GH release; however, it reversed the fasting-induced suppression of pulsatile GH secretion. The recovery of GH secretion was associated with a reduction in hypothalamic somatotropin release inhibiting factor (Srif; somatostatin) mRNA expression. Moreover, observations revealed a differential role for Y1 and Y2 receptors, wherein the postsynaptic Y1 receptor suppresses GH secretion in fasting. In contrast, the presynaptic Y2 receptor maintains normal GH output under long-term ad libitum-fed conditions. These data demonstrate an integrated neural circuit that modulates GH release relative to food intake, and provide essential information to address the differential roles of $\mathrm{Y} 1$ and $\mathrm{Y} 2$ receptors in regulating the release of GH under fed and fasting states.

Key words: fasting; feeding; growth hormone; NPY; NPY-receptors; somatostatin

\section{Introduction}

Growth hormone $(\mathrm{GH})$ secretion is under the reciprocal control of hypothalamic stimulatory growth hormone releasing hormone $(\mathrm{GHRH})$ and inhibitory somatotropin release inhibiting factor (SRIF; somatostatin) neurons (Frohman et al., 1992). A close relationship exists between GH secretion and food intake. In humans, consumption of a high-caloric diet results in the early suppression of pulsatile GH secretion (Cornford et al., 2011). Similarly, consumption of a high-fat diet suppresses pulsatile GH secretion in rodents (Huang et al., 2012). In addition, food withdrawal immediately suppresses pulsatile GH secretion in both rats (Glad et al., 2011) and mice (Steyn et al., 2012). Altered GH secretion relative to food intake may, in part, be mediated through changes in GHRH and/or SRIF secretion (Bruno et al.,

Received Oct. 30, 2013; revised 0ct. 19, 2014; accepted 0ct. 23, 2014.

Author contributions: L.H. and F.J.S. designed research; L.H., H.Y.T., M.J.F., and F.J.S. performed research; L.H., Z.B.A., J.D.V., H.H., F.J.S., and C.C. contributed unpublished reagents/analytic tools; L.H., J.V.D., and F.J.S. analyzed data; L.H., F.J.S., and C.C. wrote the paper.

This work was supported by the National Health and Medical Research Council and The University of Queensland. L.H. receives a postgraduate scholarship from the China Scholarship Council and The University of Queensland. We thank Dr. Yan Zhao, Dr. Shyuan Ngo, and Ying Wan for assisting with experiments.

The authors declare no competing financial interests.

Correspondence should be addressed to either Dr. Frederik J. Steyn or Chen Chen, School of Biomedical Sciences, University of Queensland, St. Lucia, Brisbane, Queensland, 4072 Australia. E-mail: f.steyn@uq.edu.au or chen.chen@uq.edu.au.

DOI:10.1523/JNEUROSCI.4622-13.2014

Copyright $\odot 2014$ the authors $\quad 0270-6474 / 14 / 3416309-11 \$ 15.00 / 0$
1993; Tannenbaum et al., 1996; Luque and Kineman, 2006; Steyn et al., 2012) that occur in response to hypothalamic orexigenic and anorexigenic systems.

Hypothalamic NPY neurons mediate their orexigenic effect through the activation of Y receptors (Y1, Y2, Y4, and Y5, and in mice and rabbits, the Y6 receptor; Herzog, 2003; Fetissov et al., 2004). Of these receptors, the $\mathrm{Y} 1$ receptor (Y1R) is the dominant postsynaptic receptor, whereas the $\mathrm{Y} 2$ receptor $(\mathrm{Y} 2 \mathrm{R})$ is mainly presynaptically expressed on NPY neurons (Chen and van den Pol, 1996; Balasubramaniam et al., 2007; Keen-Rhinehart and Bartness, 2007). Activation of the Y1R stimulates feeding whereas activation of Y2R inhibits NPY production and release (KeenRhinehart and Bartness, 2007; Ortiz et al., 2007). While the role of NPY and its receptors on food intake is well characterized (Herzog, 2003), their effects in regulating GH secretion remains largely unknown. Anatomical and neuropharmacological evidence provides insights into the possible interconnectivity between NPY and GH regulating systems. Early studies in rodents demonstrate an inhibitory role of NPY on the GH axis (Pierroz et al., 1996; Raposinho et al., 2001), while morphological studies in rats showed that NPY neurons in the arcuate nucleus (ARC) project to SRIF neurons located within the periventricular nucleus (PeVN; Hisano et al., 1990). Furthermore, observations in mice demonstrate an increase in hypothalamic levels of $N p y$ mRNA, alongside an increase in Srif mRNA expression following $9 \mathrm{~h}$ of fasting (Steyn et al., 2012). Given that SRIF inhibits the 
release of GH secretion, these observations suggest that NPY neurons mediate the fasting-induced suppression of GH secretion, possibly through increasing SRIF neuronal activity. Accordingly, we investigated the actions of NPY neurons, and the Y1R and Y2R in mediating pulsatile $\mathrm{GH}$ secretion under ad libitum-fed and fasting conditions.

\section{Materials and Methods}

Mice. All experiments were conducted in adult male mice (8-12 weeks of age) on either a wildtype or transgenic background. Heterozygous $\mathrm{Npy}^{+/-}, \mathrm{Y}_{1 \mathrm{R}^{+/-}}$, and $\mathrm{Y}_{2 \mathrm{R}^{+/-}}$mice, bred on a mixed C57BL/6129SvJ background, were used to generate homozygous $N p y^{-/-}, Y 1 R^{-/-}$, and $Y 2 R^{-1-}$ mice and age-matched wild-type littermates (Sainsbury et al., 2002; Howell et al., 2003; Karl et al., 2008). Mice were maintained under controlled light (12 h light/dark cycle, lights off at 18:00 h) and temperature (22 \pm $2^{\circ} \mathrm{C}$ ) conditions and had free access to food and water unless otherwise specified. Mice were individually housed at least 1 week before experiments. All experimental procedures were approved by the University of Queensland Animal Ethics Committee.

Confirmation of anatomical relationship between NPY and SRIF neurons in mice. Brain tissues from transgenic NPY-humanized $R e$ nilla reniformis-GFP mice (B6.FVB- $\mathrm{Tg}$ (NpyhrGFP)1Lowl/J; stock number 006417; The Jackson Laboratory; 9-10 weeks old; Wu et al., 2014) and C57BL/6 wild-type mice were collected for immunohistochemistry and in situ hybridization, respectively. Briefly, NpyhrGFP mice were anesthetized with isoflurane and perfused with $0.1 \mathrm{M}$ phosphate buffer, followed by $4 \%$ paraformaldehyde (Sigma-Aldrich). The brain was excised and post fixed in $4 \%$ paraformaldehyde overnight at $4^{\circ} \mathrm{C}$ and then replaced in $30 \%$ sucrose. For immunohistochemistry, coronal brain sections from Npy-hrGFP mice were cut at a thickness of $30 \mu \mathrm{m}$ on a cryostat (Leica CM 1850) and every fourth section through the hypothalamus was collected and stored in cryoprotectant (30\% sucrose, $1 \%$ polyvinyl pyrrolidone and $30 \%$ ethylene glycol in $0.1 \mathrm{M}$ phosphate buffer) at $-20^{\circ} \mathrm{C}$. Sections were incubated with primary antibodies [rabbit anti-somatostatin-14, 1:5000; Bachem; mouse monoclonal antibody against the synaptic vesicle protein 2 (SV2), a marker for synaptic sites in neurons and endocrine cells; Buckley and Kelly, 1985; 1:100; Invitrogen] diluted in blocking serum for $72 \mathrm{~h}$ at $4^{\circ} \mathrm{C}$ on an orbital shaker. Following incubation in primary antibodies, sections were washed and incubated with secondary antibodies (donkey anti-rabbit 555, 1:500; Invitrogen and donkey anti-mouse IgG 647, 1:500; Life Technologies). To visualize immunoreactivity, sections were air dried, mounted with Golden anti-fade reagent with DAPI (Invitrogen), and examined using a confocal laserscanning microscope (Olympus, FV 1000).
A
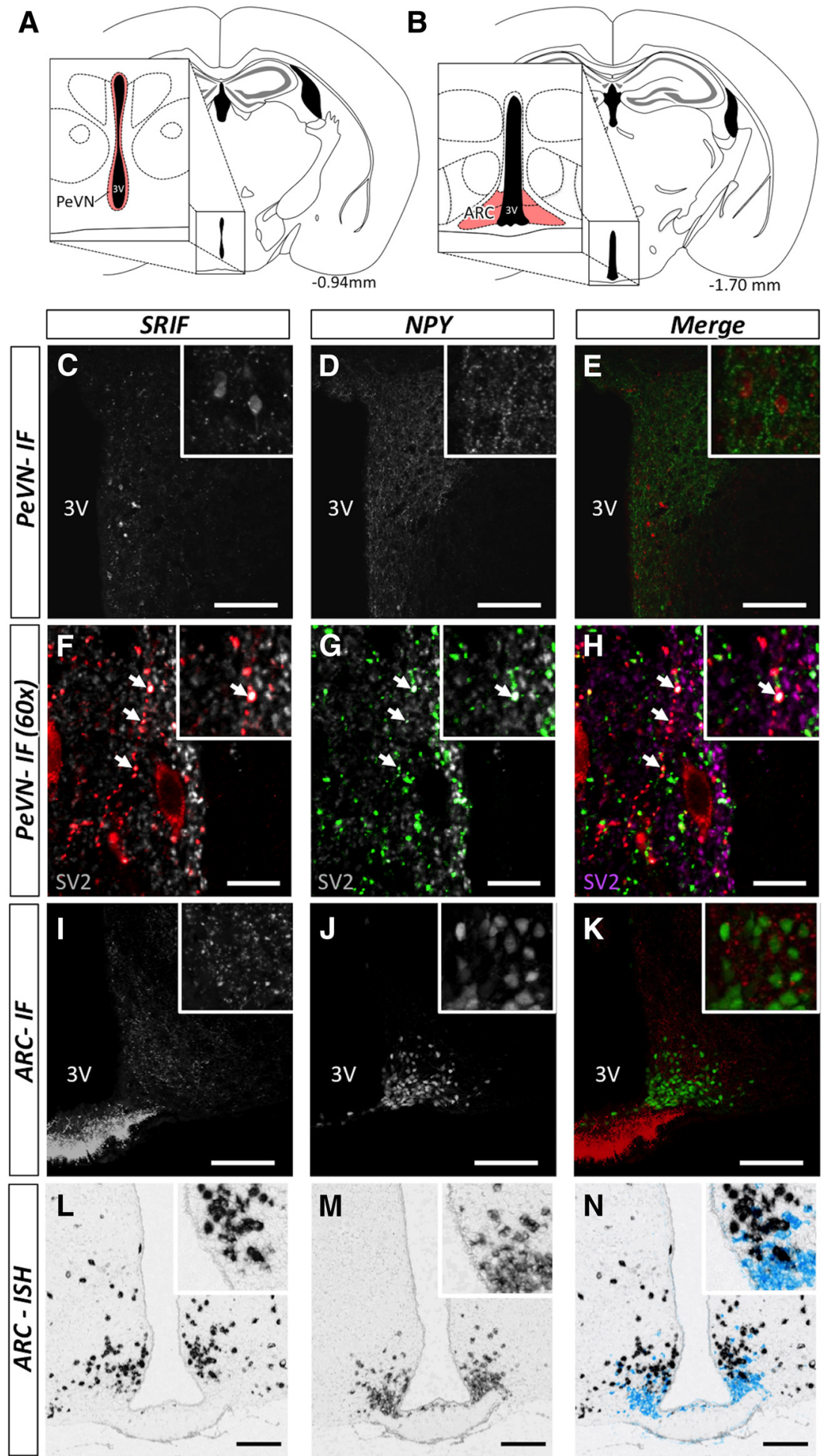

Figure 1. Illustration of anatomical interactions between SRIF and NPY-expressing neurons within the hypothalamus $(A, B)$ by immunofluorescence $(\boldsymbol{C} \boldsymbol{K})$ and in situ hybridization $(\boldsymbol{L}-\boldsymbol{N})$. Brain slices were collected between -0.94 and -1.70 bregma. Schematic representation of specific areas within the hypothalamus, representative of the PeVN $(\boldsymbol{A}$, enlarged inset, shaded areas in red) and ARC ( $\boldsymbol{B}$, enlarged inset, shaded area in red). Within the PeVN $(\boldsymbol{C}-\boldsymbol{H})$ we observed a number of SRIF-immunopositive neurons (red) in close apposition with NPY-GFP-immunopositive fibers (green; $\boldsymbol{C}-\boldsymbol{E}$ ). Further assessment using SV2 (gray; $\boldsymbol{F}$ and $\mathbf{G}$; purple; $\boldsymbol{H})$ revealed the synaptic interactions between SRIF and NPY-positive fibers $(\boldsymbol{F}-\boldsymbol{H}$; colocalization is indicated by white arrows). SRIF-positive immunoreactivity and NPY-GFP within the ARC (I-K) demonstrate punctuate SRIF expression, distributed among NPY-positive GFP neuronal cell bodies. In situ hybridization illustrates the proportion of Srif (black) and Npy (light blue) mRNA-expressing neurons within the ARC $(\boldsymbol{L}-\boldsymbol{N})$. These two populations of neurons were in close proximity. Scale bars: $\mathbf{C}-\boldsymbol{E}, \boldsymbol{I}-\boldsymbol{N}$, $100 \mu \mathrm{m} ; \boldsymbol{F}-\boldsymbol{H}, 10 \mu \mathrm{m}$. Inserts illustrate a magnified view of the figures. Representative images illustrate interactions verified across four animals. 


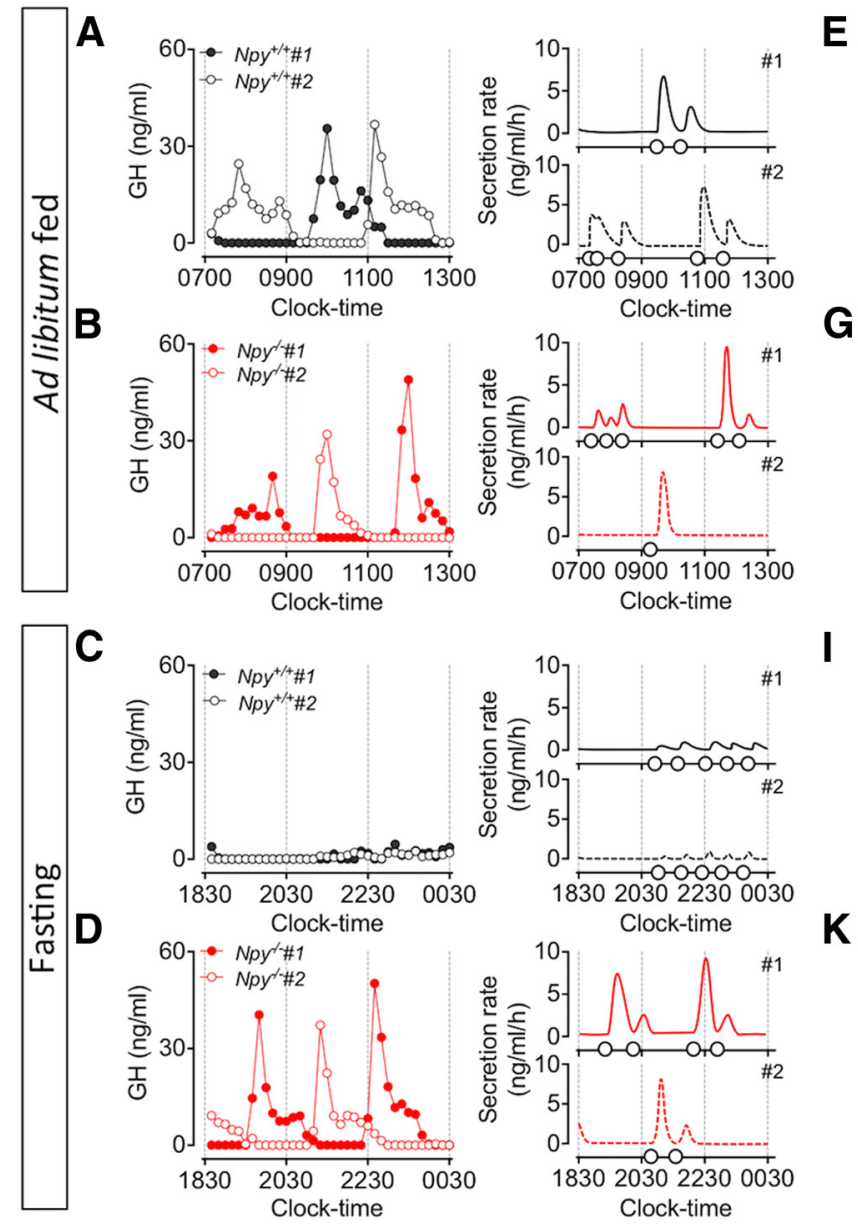

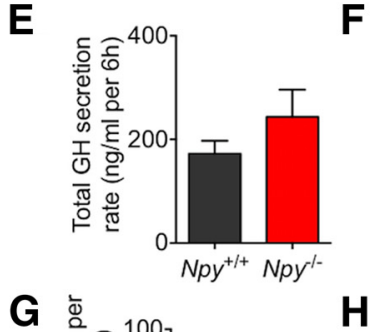
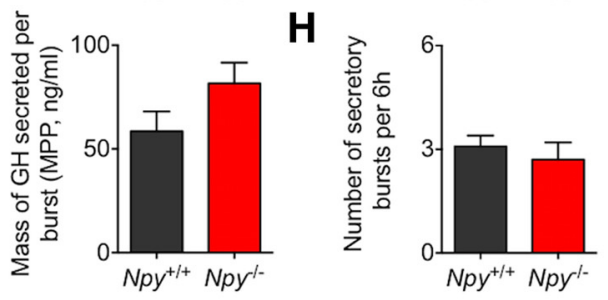

Figure 2. Representative examples of pulsatile GH secretion profiles (2 animals; \#1, closed circles; \#2, open circles; $\boldsymbol{A}-\boldsymbol{D}$, left) and corresponding output figures ( $\boldsymbol{A}-\boldsymbol{D}$, right) in male adult Npy ${ }^{-/-}$mice (red) and age-matched wild-type littermates (black). Assessment of pulsatile $\mathrm{GH}$ secretion was done in ad libitum-fed mice $(\boldsymbol{A}, \boldsymbol{B})$ and during the first $6 \mathrm{~h}$ of fasting $(\boldsymbol{C}, \boldsymbol{D})$. Samples were collected for $6 \mathrm{~h}$ at $10 \mathrm{~min}$ intervals, starting at $0700 \mathrm{~h}$ (fed) and $1830 \mathrm{~h}$ (fasting). Corresponding output figures illustrate the onset of GH pulses (pulse onset indicated by open circles along the $x$-axis). GH secretory parameters following

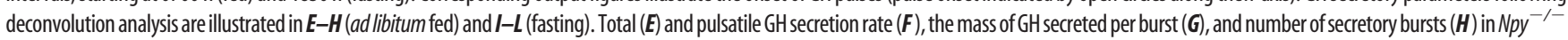
mice were comparable to ad libitum-fed wild-type mice. In contrast, the fasting-induced suppression of GH secretion observed in wild-type mice was prevented in Npy ${ }^{-/-}$mice. This was characterized by a significant increase in total $(\boldsymbol{I})$ and pulsatile $\mathrm{GH}$ secretion rate $(\boldsymbol{J})$, and the mass of GH secreted per burst $(\boldsymbol{K})$ in $\mathrm{Npy}^{-/-}$mice. The number of secretory bursts $(\boldsymbol{L})$ remained unchanged. Data are presented as mean \pm SEM, $N=10-12,{ }^{*} p<0.05$.

Images were processed using ImageJ software (version 1.46r). For In situ hybridization, two sequential coronal brain sections $(14 \mu \mathrm{m})$ were thaw mounted as mirrored images onto SuperFrost slides (Menzel-Gläser). Matched sections from the adjacent coronal brain level were processed for DIG-labeled Srif and Npy mRNA expression, following established in situ hybridization methodology (Tan et al., 2013). DNA oligonucleotides complementary to mouse Srif and Npy are 5'-TAATACGACTCACTATAGGGgggccaggagttaaggaaga-3' and 5'-TA ATACGACTCACTATAGGGgcagactggtttcaggggat-3', respectively. Sections were imaged on an Aperio ScanScope XT slide scanner (Aperio Technologies). Extracted images were opened in ImageJ and matched sections were adjusted to mirror symmetry.

Determination of pulsatile GH secretion in $\mathrm{Npy}^{-1-}$ mice under fasting and fed conditions. At 8 weeks of age, pulsatile secretion of GH was assessed in $\mathrm{Npy}^{-/-}$mice and the corresponding age-matched wildtype littermates following the first $6 \mathrm{~h}$ of food withdrawal. At the start of dark cycle, animals were deprived of food (between 1800 and 1815 h). Starting at 1830 h, 36 sequential tail-tip blood samples were collected from individual mice at $10 \mathrm{~min}$ intervals under dim red light. Blood samples were collected and processed as described previously (Steyn et al., 2011). Following collection of blood samples, mice were returned to their home cage and allowed to settle for at least 2 weeks before repeat serial blood collection under ad libitum-fed conditions (10 weeks of age, sampling commenced at $0700 \mathrm{~h}$ ). Samples were processed by an in-house GH ELISA to determine whole blood GH content (Steyn et al., 2011). One week following the second blood collection, mice were killed following $6 \mathrm{~h}$ of fasting (as detailed above). Body length was measured from nose to rump at the time of killing. Brains were collected, snap frozen, and kept at $-80^{\circ} \mathrm{C}$ for further analysis.

Analysis of hypothalamic Srif and Ghrh gene expression. We previously showed that the rise in hypothalamic Srif mRNA at $9 \mathrm{~h}$ of fasting in the mouse occurs alongside a rise in hypothalamic Npy mRNA expression. Moreover, treatment of NPY results in an increase in SRIF release from hypothalamic explants (Rettori et al., 1990). Accordingly, we anticipated that the recovery of GH release in $\mathrm{Npy}^{-1-}$ mice occurred alongside a loss in NPY-mediated SRIF release. To address this, we determined the expression of Srif and Ghrh mRNA from hypothalamic tissue biopsies from $N p y^{-/-}$mice and corresponding age-matched wild-type littermates under fasting and fed conditions. To confirm that loss of $\mathrm{Npy}^{-/-}$does not impact hypothalamic Srif and Ghrh mRNA expression under basal ad libitum-fed condition, $N p y^{-1-}$ mice and wild-type littermates were killed and brain tissues were collected between 0800 and $0900 \mathrm{~h}$. These animals had free access to food and water the night before tissue collection. To determine whether loss of NPY will result in altered Srif expression, $\mathrm{Np}^{-1-}$ mice and wild-type littermates were killed following $6 \mathrm{~h}$ of food withdrawal in the dark cycle (tissue collected between 0000 and 
$0100 \mathrm{~h}$; food was removed immediately following the onset of the dark cycle). For tissue collection, mice were anesthetized with a single intraperitoneal injection of sodium pentobarbitone $(32.5 \mathrm{mg} / \mathrm{ml}$, 1PO643-1; Virbac Animal Health). Once anesthetized, the brain from each mouse was immediately removed, snap frozen on dry ice, and stored at $-80^{\circ} \mathrm{C}$ until microdissection of specific nuclei (ARC and PeVN), following established methodology (Steyn et al., 2012). In brief, frozen brain tissue was cut $(300 \mu \mathrm{m})$ on a cryostat (Leica), and transferred to RNase free SuperFrost plus slides. Tissue biopsies representative of the ARC and PeVN located between -0.94 and -2.18 mm bregma (as shown in Fig. $3 A$ ) were processed for qRT-PCR. Total cellular RNA was extracted from brain tissues collected in TRIzol using PureLink RNA Micro Kit (Invitrogen). The final concentration and quality of RNA was determined via a spectrophotometer (NanoDrop, ND-1000; Thermo Scientific). First-strand cDNA was synthesized from 100 ng total RNA using the Vilo cDNA Synthesis kit (Invitrogen). qRT-PCR was performed using Taq polymerase (TaqMan) probes and the following primers: Ghrh, assay ID: Mm00439100_ml; Srif, assay ID: Mm00436671_ml; and Gapdh, assay ID: Mm9999915_gl. All primers were purchased from Applied Biosystems. The experiment was set up according to the protocol and reagents provided. Amplification in a $10 \mu \mathrm{l} \mathrm{reac-}$ tion volume was assessed using the QuantStudio 7 system (Applied Biosystems). Data were displayed as an amplification plot and analysis was done by ViiA7 Software v1.2 (Applied Biosystems). Changes in cycle threshold of the gene of interest were corrected to the housekeeping gene $(G a p d h)$. Final measurements of the gene expression from $N p y^{-1-}$ mice were presented as relative levels corresponding to ad libitum-fed or fasting wild-type mice.

Determination of circulating blood glucose, NPY, and peptide YY (PYY) in response to acute food deprivation. NPY neurons sense glucose (Murphy et al., 2009), and activation of hypothalamic NPY neurons occurs within $60 \mathrm{~min}$ of central glucoprivation (Minami et al., 1995). Accordingly, alterations in blood glucose levels might underlie altered NPY activity. To determine the time-dependent response of circulating levels of glucose relative to food withdrawal, blood glucose was assessed from tail blood using the Accu-Chek Performa blood glucose meter (Roche). Blood glucose measures were collected at $15 \mathrm{~min}$ intervals for a period of $2.5 \mathrm{~h}$, starting at $1800 \mathrm{~h}$ (food was removed immediately following the onset of the dark cycle). Circulating gut hormone PYY is secreted in response to food ingestion and is a natural ligand of Y receptors (Batterham et al., 2002). Changes in circulating PYY may underlie Y-receptor-mediated GH secretion. Accordingly, circulating levels of PYY in response to fasting were determined by commercial ELISA kit (mouse metabolic magnetic bead panel, \#MMHMAG-44K; Millipore) using terminal blood samples collected from C57BL/6 mice at 0,45 , and $90 \mathrm{~min}$ following the onset of food withdrawal. Samples were collected via cardiac puncture from anesthetized mice, and sampling intervals were selected based on observations from glucose measurements. Although peripheral NPY is largely a marker of sympathetic nervous system activity (Zukowska-Grojec et al., 1998), a number of studies in both humans and rats have demonstrated effects of NPY on GH secretion in pituitary cells (Adams et al., 1987; Chabot et al., 1988). Accordingly, we determined circulating levels of NPY in fasting mice to determine whether alterations in circulating levels of NPY may contribute to the suppression of GH release at this time. Circulating NPY was assessed by commercial ELSIA kit (rat/mouse NPY, \#EZRMNPY-27K; Millipore) from terminal samples collected as described above.

Assessment of pulsatile GH secretion in $\mathrm{Y}_{1} \mathrm{R}^{-1-}$ and $\mathrm{Y} 2 \mathrm{R}^{-1-}$ mice under fasting and ad libitum-fed conditions. To determine whether the NPY-mediated GH secretion occurs via postsynaptic Y1R or presynaptic Y2R-mediated mechanisms, pulsatile GH secretion was further determined in germline $\mathrm{Y} 1$ or $\mathrm{Y} 2$ receptor knock-out mice and respective age-matched wild-type littermates under ad libitum-fed and fasting conditions. Experimental procedures were similar to that conducted in $\mathrm{Npy}^{-/-}$mice (as described above).

Statistical analysis. The quantitative features underlying GH secretion and clearance associated with the observed GH concentration profiles were determined at a fixed half-life of $7.95 \mathrm{~min}$ by deconvolution analysis, as described previously (Huang et al., 2012). Resulting output measures are indicative of the secretion of GH from the pituitary gland, and thus a measure of hypothalamic-mediated pituitary activity that accounts for the observed circulating measures of GH. All data are presented as mean \pm SEM unless otherwise stated. Differences between groups were identified by two-tailed unpaired $t$ test unless otherwise stated. All measures (excluding deconvolution analysis) were performed using GraphPad Prism 6.0e. The threshold level for statistical significance was set at $p<0.05$.

\section{Results}

\section{Hypothalamic NPY neurons are structurally integrated with} hypothalamic SRIF neurons

Immunofluorescence assessment of hypothalamic NPY and SRIF expression demonstrates close apposition of NPY-immunopositive fibers with SRIF-expressing neurons, specifically within the PeVN (Fig. 1C-E). Insets illustrate close apposition of NPY-GFP fibers with SRIF-immunoreactive cell bodies, while the $60 \times$ magnified view (Fig. $1 F-H$ ) demonstrates SV2 immunoreactivity in both SRIF (Fig. $1 F$ ) and NPY-immunopositive fibers (Fig. $1 \mathrm{G}$ ), and colocalization of SV2, SRIF, and NPY immunoreactivity (Fig. $1 H$ ). Thus, synaptic interactions occur between SRIF and NPY neurons. Immunofluorescence assessment of NPY-GFP and SRIF-positive immunoreactivity within the ARC demonstrate punctate SRIF expression, distributed among NPY-positive GFP neuronal cell bodies (Fig. 1I$K)$. Given that SRIF within the ARC was not clearly localized to cell bodies, we completed in situ hybridization assessment of Npy (Fig. $1 L$ ) and Srif (Fig. 1M) mRNA within this region. In situ hybridization confirmed the close proximity of Npy and Srif mRNAexpressing neurons (Fig. $1 N$ ). Collectively, observations provide a structural basis for potential physiological interactions between hypothalamic NPY and SRIF-expressing neurons.

\section{Deletion of NPY prevents fasting-induced suppression in GH secretion in mice}

Representative secretory profiles and output figures illustrate the onset of pulsatile GH secretion in ad libitum-fed $N p y^{-/-}$and corresponding wild-type mice (Fig. $2 A, B$ ), and the same mice following $6 \mathrm{~h}$ of fasting (Fig. 2C,D). Peaks in GH secretion occurred at regular intervals, and were dispersed by periods of low basal levels of secretion. There was no significant difference in $\mathrm{GH}$ release (including total; Fig. $2 E ; t_{(20)}=1.29, p=0.21$ ) and pulsatile (Fig. $2 F ; t_{(20)}=1.30, p=0.27$ ) GH secretion, the mass of GH secreted per burst (Fig. $2 G$; $t_{(20)}=1.67, p=0.11$ ), and the number of secretory events (Fig. $2 H ; t_{(20)}=0.67, p=0.51$ ) between $\mathrm{Npy}^{-/-}$mice and corresponding wild-type mice under $\mathrm{ad}$ libitum-fed conditions, as determined by deconvolution analysis. During fasting, pulsatile GH secretion was significantly suppressed in wild-type mice (Fig. 2C) whereas GH secretion was sustained in $\mathrm{Npy}^{-/-}$mice (Fig. 2D). Deconvolution analysis of pulsatile measures of GH confirmed that deletion of NPY recovered GH secretion. This is characterized by a recovery in total (Fig. $2 I ; t_{(20)}=5.88, p<0.01$ ), pulsatile (Fig. $2 J ; t_{(20)}=5.54, p<$ 0.01 ), and mass of $\mathrm{GH}$ secretion per pulse (Fig. $2 K ; t_{(20)}=3.57$, $p<0.01$ ), whereas the number of secretory bursts remained unchanged (Fig. $2 L ; t_{(20)}=0.72, p=0.48$ ). Of interest, $N p y$ mRNA exhibits circadian rhythm in gene expression with highest levels observed early in the dark cycle (Kohsaka et al., 2007). This suggests NPY neurons are primed at this time, and is in agreement with the immediate cessation of GH secretion as observed in wild-type mice following food withdrawal (Fig. 2C). 
A
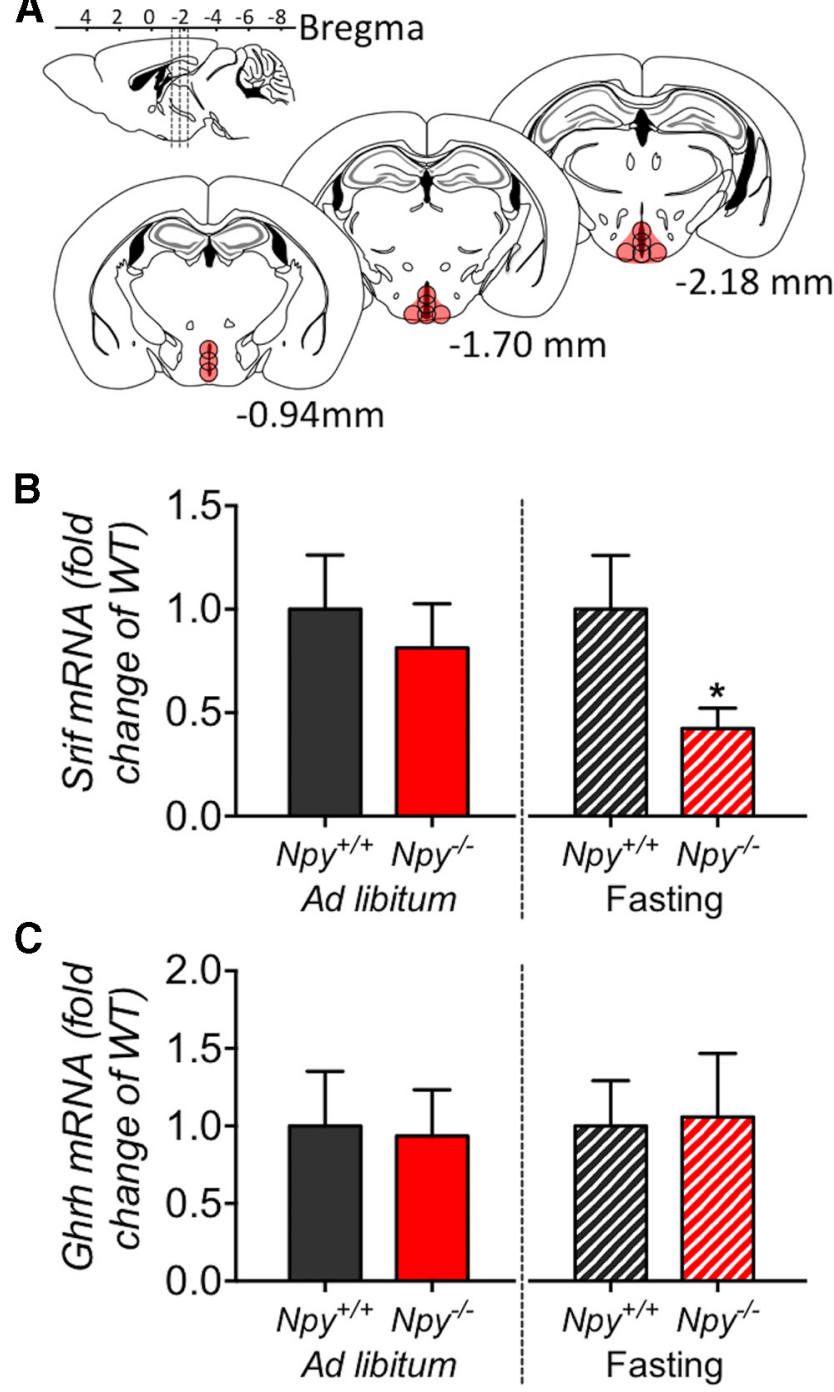

Figure 3. Comparison of Ghrh and SrifmRNA expression within the ARC/PeVN of $\mathrm{Npy}^{-/-}$mice and corresponding WT mice under ad libitum-fed conditions and following $6 \mathrm{~h}$ of fasting. Micropunch biopsies of tissue representing the ARC/PeVN (between -0.94 and -2.18 bregma) were collected from frozen brain sections ( $A$, location of punch biopsies illustrated in red). Compared with wild-type mice, deletion of NPY did not result in a significant difference in Srif ( $\boldsymbol{B}$, left) or Ghrh ( $\boldsymbol{C}$, left) mRNA expression under ad libitum-fed conditions. In contrast, deletion of NPY resulted in a reduction of Srif mRNA expression ( $\boldsymbol{B}$, right) following $6 \mathrm{~h}$ of fasting. Ghrh mRNA expression remained unchanged ( $\boldsymbol{C}$, right). Data are presented as mean $\pm \mathrm{SEM}, N=5-6,{ }^{*} p<0.05$

The recovery of GH secretion in $N p y^{-/-}$mice following $6 \mathrm{~h}$ of fasting is associated with a reduction in hypothalamic Srif mRNA expression

Our previous results demonstrate that reduced GH secretion in fasting wild-type mice coincides with elevated Srif mRNA expression (Steyn et al., 2012). To further determine whether the recovery of pulsatile GH secretion in $\mathrm{Npy}^{-/-}$mice in response to fasting is associated with changes in primary hypothalamic $\mathrm{GH}$ regulators, Ghrh and Srif gene expression was assessed. Loss of NPY did not impact ARC/PeVN Srif (Fig. 3B, left; $t_{(8)}=1.03, p=$ 0.55 ) or Ghrh (Fig. $3 C$, left; $t_{(8)}=0.21, p=0.84$ ) mRNA expression under ad libitum-fed conditions. In contrast, Srif mRNA expression was significantly reduced in $N p y^{-1-}$ mice following the first $6 \mathrm{~h}$ of food withdrawal (Fig. $3 B$, right; $t_{(9)}=2.74, p<$ $0.05)$, indicating that fasting may induce NPY-activated SRIF expression. No change in Ghrh mRNA expression within the ARC/ PeVN area was observed (Fig. $3 C$, right; $t_{(9)}=0.15, p=0.88$ ).
A

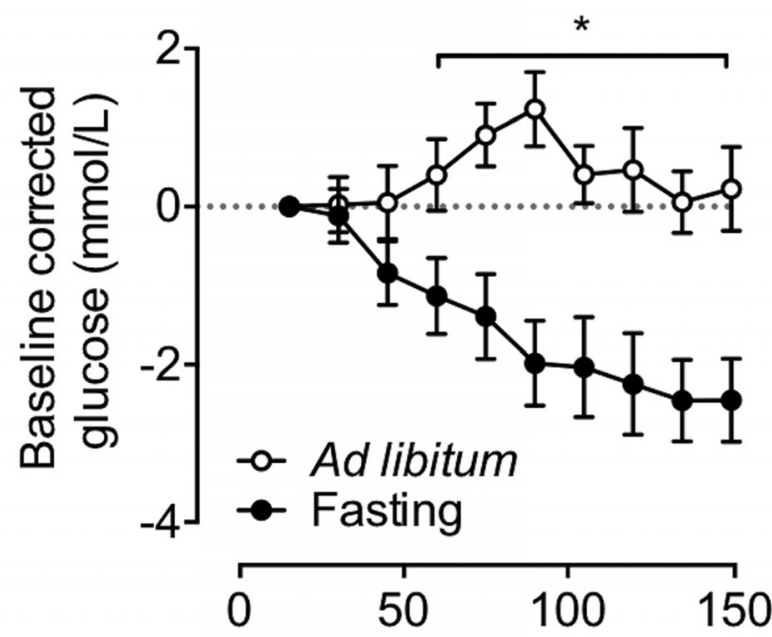

B

Time following onset of fast (minutes)
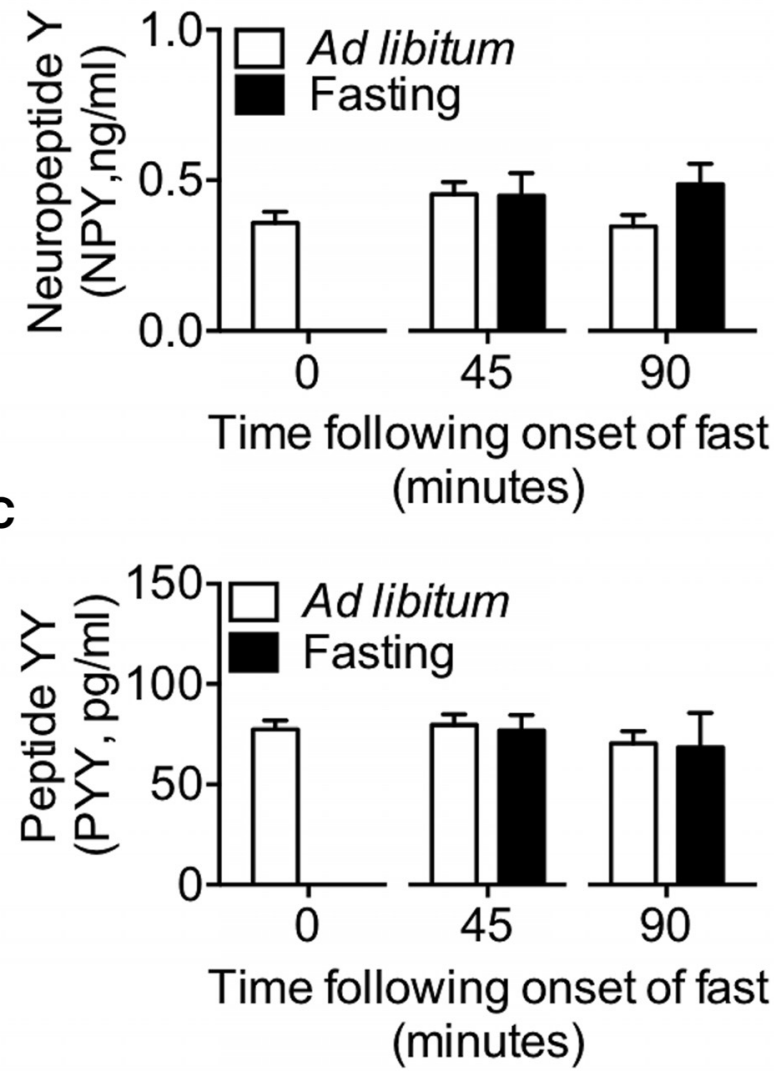

Figure 4. Assessment of circulating levels of blood glucose, NPY, and PYY in response to fasting. Glucose was measured every $15 \mathrm{~min}$ for a duration of $150 \mathrm{~min}$, and corrected to starting levels $(\boldsymbol{A})$. Circulating levels of NPY $(\boldsymbol{B})$ and PYY $(\boldsymbol{C})$ were determined following 45 and $90 \mathrm{~min}$ of fasting. Fasting resulted in a decline in circulating levels of glucose by $45 \mathrm{~min}$ of food withdrawal (A). Unlike glucose, circulating levels of NPY and PYY remained unchanged for the duration of the fasting period (B, $\boldsymbol{C}$. Data are presented as mean $\pm \mathrm{SEM}, N=12,{ }^{*} p<0.05$.

Fasting rapidly reduces circulating glucose levels, whereas circulating NPY and PYY levels remain unchanged Increased NPY activity occurs in response to glucoprivation (Minami et al., 1995), and thus may underlie the trigger for the suppression of $\mathrm{GH}$ release in fasting mice. Circulating levels of glucose declined by $45 \mathrm{~min}$ of food withdrawal (Fig. $4 A$; two-way 

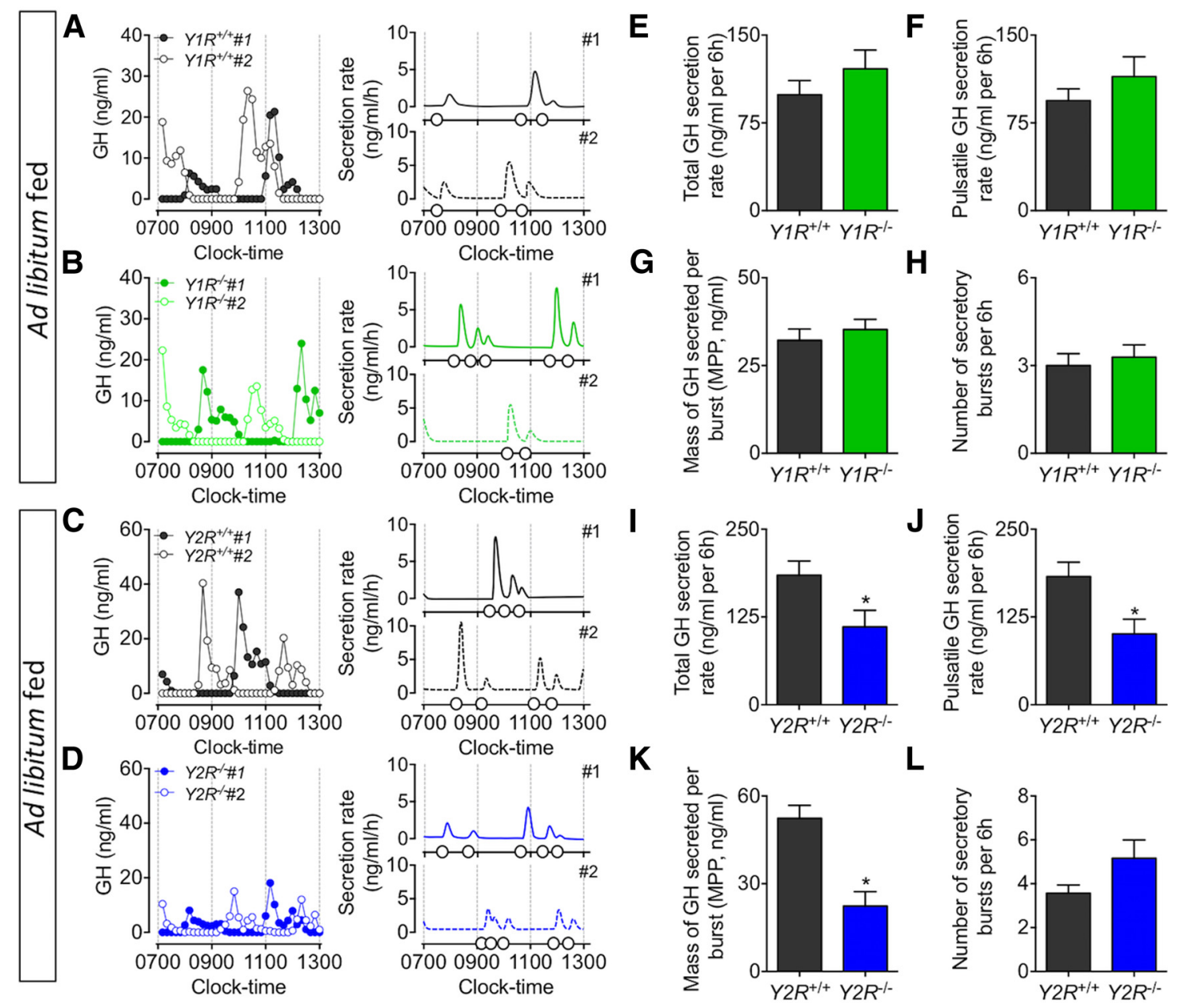

Figure 5. Representative examples of pulsatile GH secretion profiles ( 2 animals; \#1, closed circles; $\# 2$, open circles; $\boldsymbol{A}-\boldsymbol{D}$, left) and corresponding output figures (A-D, right) from ad libitum-fed male adult mice with germline deletion of $\mathrm{Y1}\left(Y 1 R^{-/-} ;\right.$green, $\left.\boldsymbol{B}\right)$ or $Y 2\left(Y 2 R^{-/-} ;\right.$blue, $\left.\boldsymbol{D}\right)$ receptors and age-matched littermates (black, $\boldsymbol{A}$ and $\boldsymbol{C}$ under ad libitum-fed conditions. Samples were collected for $6 \mathrm{~h}$ at 10 min intervals, starting at $0700 \mathrm{~h}$. Corresponding output figures illustrate the onset of $\mathrm{GH}$ pulses (pulse onset indicated by open circles along the $x$-axis). GH secretory parameters following deconvolution analysis are illustrated in $\boldsymbol{E}-\boldsymbol{H}\left(Y 1 R^{-\prime-}\right)$ and $\boldsymbol{I}-\boldsymbol{L}\left(Y 2 R^{-1-}\right)$. Total $(\boldsymbol{E})$ and pulsatile $\mathrm{GH}$ secretion rate $(\boldsymbol{F})$, the mass of $\mathrm{GH}$ secreted per burst $(\boldsymbol{G})$, and number of secretory bursts $(\boldsymbol{H})$ in $Y 1 R^{-/-}$mice were comparable to ad libitum-fed wild-type mice. $\mathrm{GH}$ secretion was significantly reduced in $Y 2 R^{-/-}$mice as characterized by a significant reduction in total $(\boldsymbol{I})$, pulsatile $(\boldsymbol{J})$, and the mass of $\mathrm{GH}$ secreted per burst $(\boldsymbol{K})$. While not significant, the number of secretory bursts $(\boldsymbol{L})$ was elevated in $Y 2 R^{-1-}$ mice $(p=0.06)$. Data are presented as mean $\pm S E M, N=4-7,{ }^{*} p<0.05$.

ANOVA; $p<0.01$ ). In ad libitum-fed animals, blood glucose levels were maintained relative to starting measures, and increased slightly relative to the onset of nighttime feeding. Plasma NPY and PYY concentrations remained unchanged following 45 $\min \left(\right.$ Fig. $4 B ; t_{(22)}=0.05, p=0.96$ and $C ; t_{(22)}=0.29, p=0.77$, respectively) and $90 \mathrm{~min}$ of fasting (Fig. $4 B ; t_{(22)}=1.79, p=0.09$ and $C ; t_{(22)}=0.11, p=0.91$, respectively). These observations suggest that circulating NPY and PYY in early fasting does not contribute to the NPY-mediated suppression of GH secretion and supports the central actions of NPY in suppressing GH release, presumably following alterations in blood glucose concentration.

The Y1R mediates GH secretion following acute fasting, whereas the Y2R modulates GH secretion under basal ad libitum-fed conditions

To determine whether the recovery of pulsatile GH secretion observed in $\mathrm{Npy}^{-1-}$ mice following $6 \mathrm{~h}$ of fasting is assigned to specific receptor subtypes, pulsatile GH secretion was further assessed in postsynaptic Y1R and presynaptic Y2R germline knockout mice. GH secretory profiles from ad libitum-fed $Y 1 R^{-1-}$ and $Y 2 R^{-/-}$mice display regular pulsatile secretory patterns, charac- terized by spontaneous GH secretory events (Fig. $5 A-D$ ). The deletion of $\mathrm{Y} 1 \mathrm{R}$ did not affect $\mathrm{GH}$ secretion in ad libitum-fed mice (including total; Fig. $5 E ; t_{(9)}=0.95, p=0.37$ ) and pulsatile (Fig. $\left.5 F ; t_{(9)}=0.85, p=0.42\right) \mathrm{GH}$ secretion, the mass of GH secreted per burst (Fig. $5 G ; t_{(9)}=0.67, p=0.52$ ), and the number of secretory events (Fig. $5 H ; t_{(9)}=0.45, p=0.67$ ), whereas the loss of $\mathrm{Y} 2 \mathrm{R}$ resulted in a significant decline in peak GH secretion, as demonstrated by a reduction in total (Fig. $5 I ; t_{(12)}=2.37, p<$ 0.05 ) and pulsatile (Fig. $\left.5 \mathrm{~J} ; t_{(12)}=2.79, p<0.05\right) \mathrm{GH}$ secretion, and the mass of GH secreted per burst (Fig. $5 K$; $t=(12)=4.55$, $p<0.01$ ). Of interest, germline Y2R deletion increased pulse number (although this did not reach significance; Fig. $5 L ; t_{(12)}=$ $1.25, p=0.24$ ) and pulse irregularity (as measured by approximate entropy; ApEn, a measure of pulse irregularity; Veldhuis et al., $2001 ; 0.45 \pm 0.05$ vs $\left.0.64 \pm 0.03, t_{(12)}=3.37, p<0.01\right)$. GH secretory profiles from fasting $Y 1 R^{-1-}$ and $Y 2 R^{-1-}$ mice demonstrate a differential role for these receptors in fasting-mediated GH release (Fig. $6 A-D)$. Deletion of Y1R prevented the fastinginduced suppression of pulsatile GH release (including total; Fig. $6 E ; t_{(9)}=6.43, p<0.01$ ) and pulsatile (Fig. $6 F ; t_{(0)}=6.80, p<$ 0.01 ) GH secretion, the mass of GH secreted per burst (Fig. $6 G$; $\left.t_{(9)}=6.71, p<0.01\right)$, whereas fasting still suppressed pulsatile 

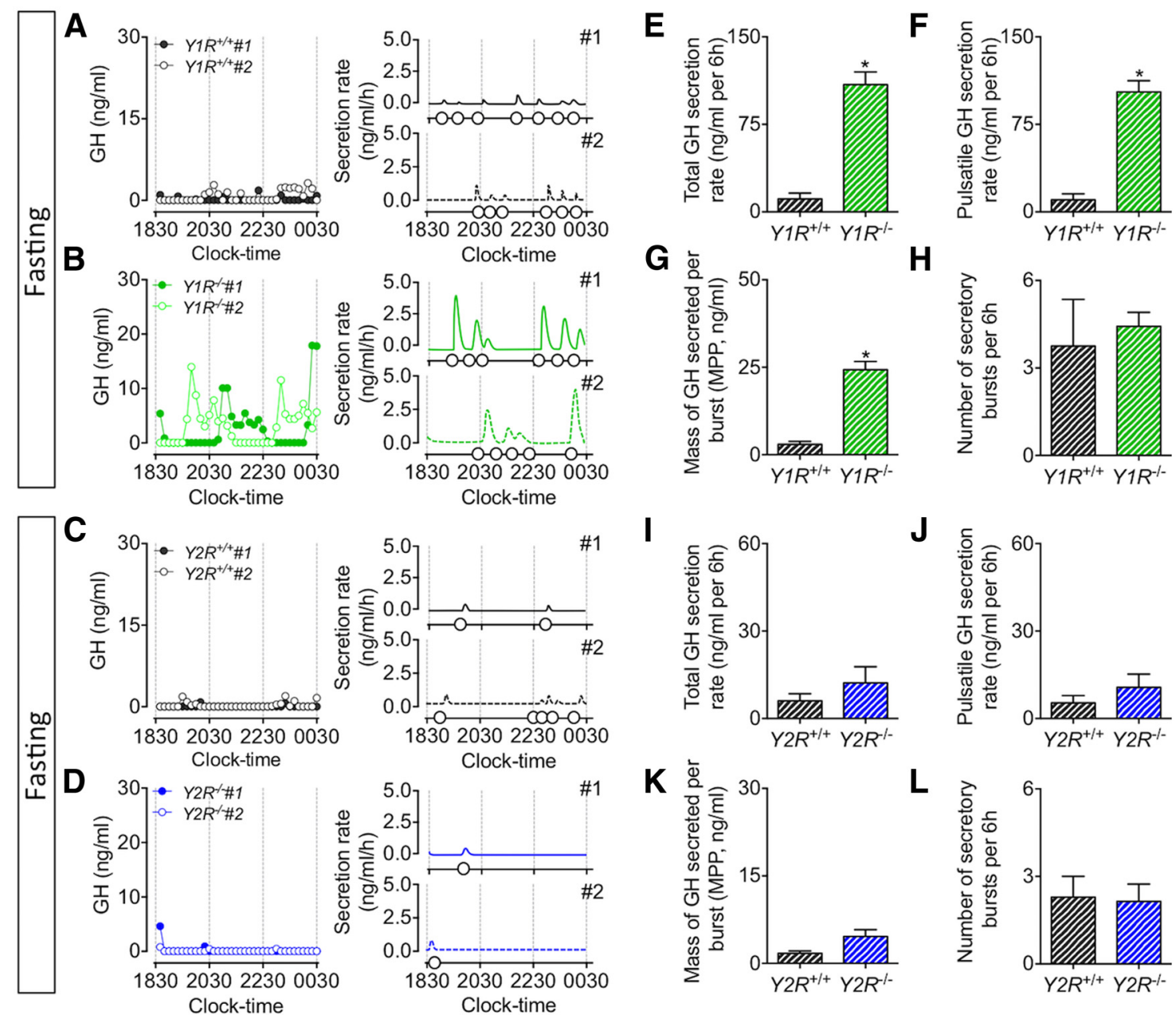

Figure 6. Representative examples of pulsatile GH secretion profiles (2 animals; \#1, closed circles; \#2, open circles; $\boldsymbol{A}-\boldsymbol{D}$, left) and corresponding output figures ( $\boldsymbol{A}-\boldsymbol{D}$, right) from male adult mice with germline deletion of the $\mathrm{Y} 1\left(Y 1 R^{-/-}\right.$; green, $\left.\boldsymbol{B}\right)$ and $\mathrm{Y} 2\left(Y_{2} R^{-/-}\right.$; blue, $\left.\boldsymbol{D}\right)$ receptor and age-matched littermates (black, $\boldsymbol{A}$ and $\left.\boldsymbol{C}\right)$ following $6 \mathrm{~h}$ of food withdrawal. Samples were collected for $6 \mathrm{~h}$ at $10 \mathrm{~min}$ intervals, starting at $1830 \mathrm{~h}$. Corresponding output figures illustrate the onset of $\mathrm{GH}$ pulses (pulse onset indicated by open circles along the $x$-axis). $\mathrm{GH}$ secretory parameters following deconvolution analysis are illustrated in $\boldsymbol{E}-\boldsymbol{H}\left(Y 1 R^{-/-}\right)$and $\boldsymbol{I}-\boldsymbol{L}\left(Y 2 R^{-/-}\right)$. Deletion of $Y 1 R$ resulted in a prevention of the fasting-induced suppression of pulsatile $G H$ release, and was characterized by an increase in total $(\boldsymbol{E})$ and pulsatile $\mathrm{GH}$ secretion rate $(\boldsymbol{F})$, and the mass of $\mathrm{GH}$ secreted per burst $(\boldsymbol{G})$. In contrast, pulsatile $\mathrm{GH}$ release was suppressed in fasting $Y 2 R^{-/-}$mice. This was characterized by a comparable total $(\boldsymbol{I})$ and pulsatile $G H$ secretion $(\boldsymbol{J})$, and the mass of $\mathrm{GH}$ secreted per burst $(\boldsymbol{K})$ when compared with age-matched fasting wild-type littermates. Data are presented as mean $\pm \mathrm{SEM}, N=4-7,{ }^{*} p<0.05$.

GH release in $Y 2 R^{-1-}$ mice (as total; Fig. $6 I ; t_{(12)}=1.00, p=0.33$ ) and pulsatile (Fig. $6 J ; t_{(12)}=1.02, p=0.33$ ) GH secretion, the mass of GH secreted per burst (Fig. $6 K ; t_{(12)}=2.17, p=0.05$ ). The number of secretory events in fasting $Y 1 R^{-/-}$(Fig. $6 H ; t_{(9)}=$ $0.51, p=0.62$ ) and Y2R ${ }^{-1-}$ (Fig. $\left.6 L ; t_{(12)}=0.15, p=0.88\right)$ mice did not change relative to wild-type littermates. Collectively, our observations suggest that Y1 and Y2 receptors differentially regulate pulsatile $\mathrm{GH}$ release, wherein the Y1R modulates fasting control of GH release while the Y2R regulates pulse dynamics under ad libitum-fed conditions. We observed a significant reduction in body length specific to $Y 2 R^{-1-}$ mice (Fig. $7 C ; t_{(12)}=$ $6.10 p<0.01$ ), whereas body length between wild-type littermates and $N P Y^{-1-}$ (Fig. $7 A ; t_{(20)}=1.68, p=0.11$ ) and $Y 1 R^{-1-}$ (Fig. $\left.7 B ; t_{(9)}=0.49, p=0.64\right)$ mice remained unchanged. Given the role of $\mathrm{GH}$ in promoting linear growth (Attanasio and Shalet, 2007), we suggest reduced peak GH release contributes to the observed reduction in body length in $Y 2 R^{-/-}$mice.

\section{Discussion}

Central injection of NPY inhibits GH secretion (Rettori et al., 1990), although the endogenous role of NPY in modulating GH release remains unknown. We provide evidence supporting functional interactions between hypothalamic NPY neurons, Y-receptors, and key components of the GH axis.

Fasting in the mouse immediately decreases pulsatile GH release (Steyn et al., 2012) and this coincides with an early rise in Npy and Srif mRNA expression within the hypothalamic ARC/PeVN complex. In comparison, Ghrh mRNA expression remains unchanged (Steyn et al., 2012). Thus, we anticipate that NPY neurons selectively activate SRIF neurons to suppress GH release. Using immunofluorescence and in situ hybridization, we confirmed synaptic interactions between hypothalamic NPY and SRIF-expressing neurons. This agrees with prior observations in rats (Kawano and Daikoku, 1988; Hisano et al., 1990).

Germline deletion of NPY does not alter GH pulsatility nor does it impact hypothalamic Ghrh and Srif mRNA expression in ad libitum-fed mice. Accordingly, NPY neurons do not modulate $\mathrm{GH}$ release under fed conditions. The suppression of GH secretion normally observed in fasting mice (Steyn et al., 2011, 2012) was completely reversed in $N p y^{-1-}$ mice. This occurred alongside reduced hypothalamic Srif mRNA expression. Our data sug- 
A

B
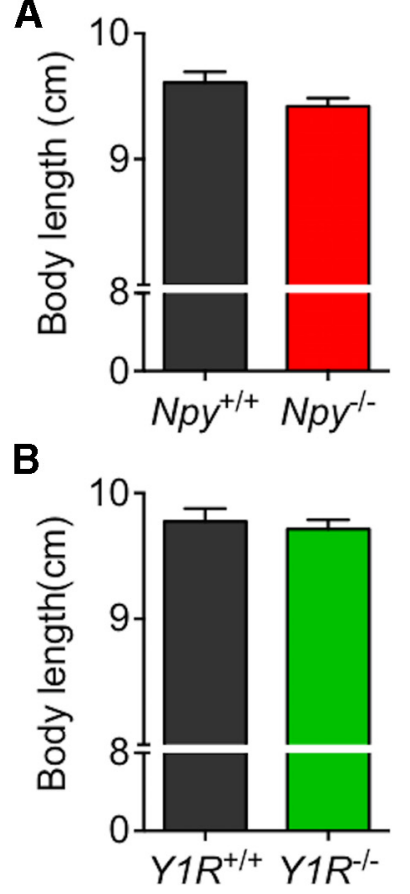

C

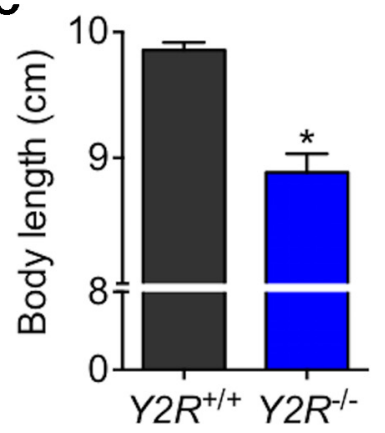

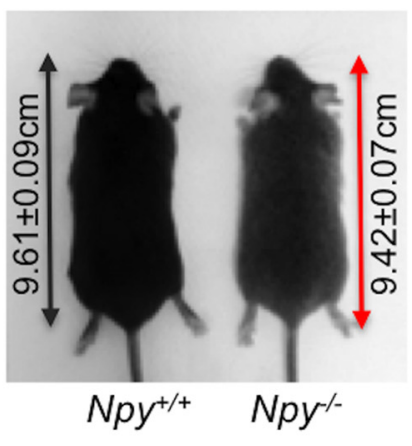
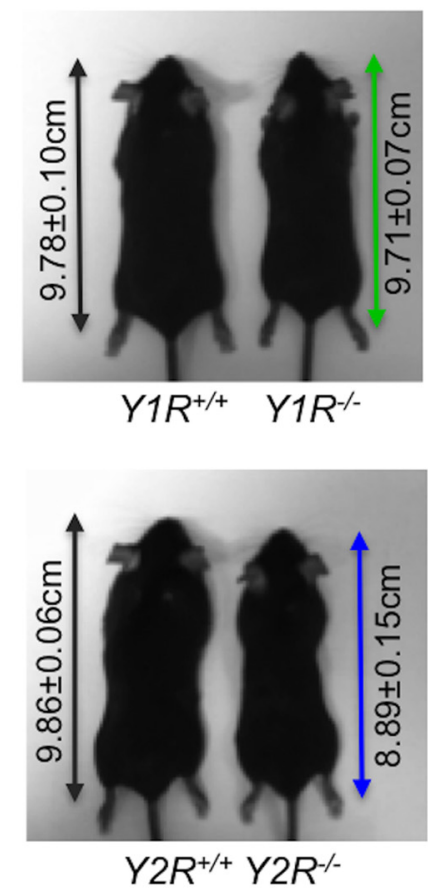

Figure 7. Body length and representative images of adult mice following germline deletion of NPY $\left(\mathrm{Npy}^{-/-} ; \boldsymbol{A}\right), \mathrm{Y} 1 \mathrm{R}\left(\mathrm{Y} 1 \mathrm{R}^{-/-} ; \boldsymbol{B}\right)$, and $\mathrm{Y} 2 \mathrm{R}\left(\mathrm{Y}_{2} \mathrm{R}^{-/-} ; \mathrm{C}\right)$. Body length in $\mathrm{Npy}^{-1-}$ and $\mathrm{Y}_{1} \mathrm{R}^{-/-}$mice was comparable to the age-matched wild-type mice, whereas $Y 2 R^{-/-}$mice were significantly shorter compared with age-matched wild-type littermates. Body length was measured from nose to rump as indicated by the double arrow line. Data are presented as mean \pm SEM, $N=4-12,{ }^{*} p<0.05$.

gest NPY neurons modulate SRIF neuronal activity and couple the suppression of GH release relative to food withdrawal. This functional interaction agrees with observations in which NPY stimulated the release of SRIF from cultured rat median eminence fragments (Rettori et al., 1990). Observations provide a physiological context for interactions between the SRIF neurons in the PeVN and NPY neurons in the ARC, wherein NPY-induced suppression of $\mathrm{GH}$ release can be prevented following structural disruption in NPY/SRIF connectivity (Minami et al., 1998).

Plasma glucose concentrations were significantly reduced within $45 \mathrm{~min}$ of food withdrawal. ARC NPY neurons are glucose sensitive (Claret et al., 2007; Murphy et al., 2009), and are activated by a decrease in extracellular glucose (Minami et al., 1995). We suggest diminishing glucose levels in mice following food withdrawal activates NPY neurons, which subsequently stimulate SRIF neurons to inhibit GH release. As NPY neurons remain inactive when food is sufficient (Becskei et al., 2009), deletion of NPY does not impact the release of GH in ad libitum-fed mice. Recent in vitro observations argue that a decrease in extracellular glucose concentrations activate glucose-sensing GHRH neurons

(Stanley et al., 2013). If this occurs in vivo, a fall in blood glucose levels should increase GH release; however, hypoglycemia associated with fasting reduces GH release. In light of this, we anticipate that NPY neurons act as gatekeepers to control GHRH activity, activating SRIF neurons to suppress GHRH-induced GH release, regardless of potential GHRH glucose-sensing effects (Stanley et al., 2013).

The actions of NPY are mediated via a family of high-affinity receptors (Pedragosa-Badia et al., 2013). The Y1R is the dominant postsynaptic receptor regulating food intake (Keen-Rhinehart and Bartness, 2007), whereas the Y2R is an auto-receptor that inhibits the synthesis and release of NPY (Broberger et al., 1997). As seen in $N p y^{-/-}$mice, pulsatile GH secretion in $Y 1 R^{-/-}$mice did not change in ad libitum-fed mice, whereas the fasting-induced suppression of GH release was completely reversed. This corroborates observations in rats, where central administration of a Y1R agonist suppressed circulating levels of GH (Suzuki et al., 1996). While the Y1R is expressed on SRIF neurons within the dorsal horn of the spinal cord (Zhang et al., 1999), coexpression of Y1R on SRIF neurons within the ARC or PeVN is yet to be confirmed. The Y1R is widely expressed within the PeVN and PVN (Kishi et al., 2005), areas characterized by the abundant expression of Srif mRNA (Tan et al., 2013), and thus Y1Rs may directly act within SRIF neurons to modulate $\mathrm{GH}$ release.

The Y1R commonly signals via inhibitory $G\left(G_{i}\right)$-proteinsignaling pathways. For example, NPY (acting through the Y1R) inhibits $\mathrm{GnRH}$ activity via the $\mathrm{G}_{\mathrm{i}}$ signaling cascade (Klenke et al., 2010). This inhibitory role contradicts the anticipated stimulatory role of the Y1R in modulating SRIF-mediated changes in $\mathrm{GH}$ release. It is possible that the Y1R functions through a yet undefined intermediate neuron to modulate SRIF activity. The Y1R may silence this intermediate neuron that would normally suppress the activity of SRIF neurons, resulting in the inhibition of GH release (Fig. 8, Scenario A). Importantly, acting through the Y1R, NPY increased calcium currents in a proportion of vagal sensory neurons, acting via $G_{i} / G_{o}$ proteins (Colmers and Bleakman, 1994). Thus potential direct stimulatory actions of Y1R on SRIF neurons cannot be excluded. Alternatively, the Y1R may alter SRIF activity, acting through coupling of G $\beta$ and G $\gamma$ subunits. The proliferative effects of NPY on dentate $\beta$-tubulinpositive neuroblasts are mediated via the Y1R, and require ERK1/2 activation (Howell et al., 2005). Similarly, the observed proliferative effects of neuronal precursor cells within the adult olfactory epithelium occur via stimulation of the Y1R, and are mediated downstream through a kinase cascade involving PKC and ERK1/2 (Hansel et al., 2001). Given these effects, NPY may mediate SRIF activity via the Y1R, acting independent of classical $\mathrm{G}_{\mathrm{i}}$-mediated pathways (Fig. 8, Scenario B). Data confirming the coexpression of the Y1R on SRIF neurons does not exist, and the direct role of Y1R on SRIF activity remains unconfirmed.

Fasting reduces pituitary GH immunoreactivity in wild-type but not $Y 2 R^{-1-}$ mice (Lin et al., 2007), providing evidence for Y2R-mediated GH synthesis. These observations do not directly test whether the Y2R modulates GH release. We now demonstrate that the $\mathrm{Y} 2 \mathrm{R}$ does not contribute to suppressed $\mathrm{GH}$ release in fasting mice. Rather, the Y2R regulates peak GH release in ad libitum-fed mice. Moreover, extended analysis of ApEn demonstrates a rise in pulse irregularity in $Y 2 R^{-1-}$ mice, signifying an overall derangement of GH pulse profile. Thus, the Y2R likely regulates interactions between hypothalamic $\mathrm{GH}$ pulse generators, the SRIF and GHRH neurons. This is consistent with the reduced body length seen in $Y_{2} \mathrm{R}^{-/-}$mice. Therefore, while the Y2R directly 


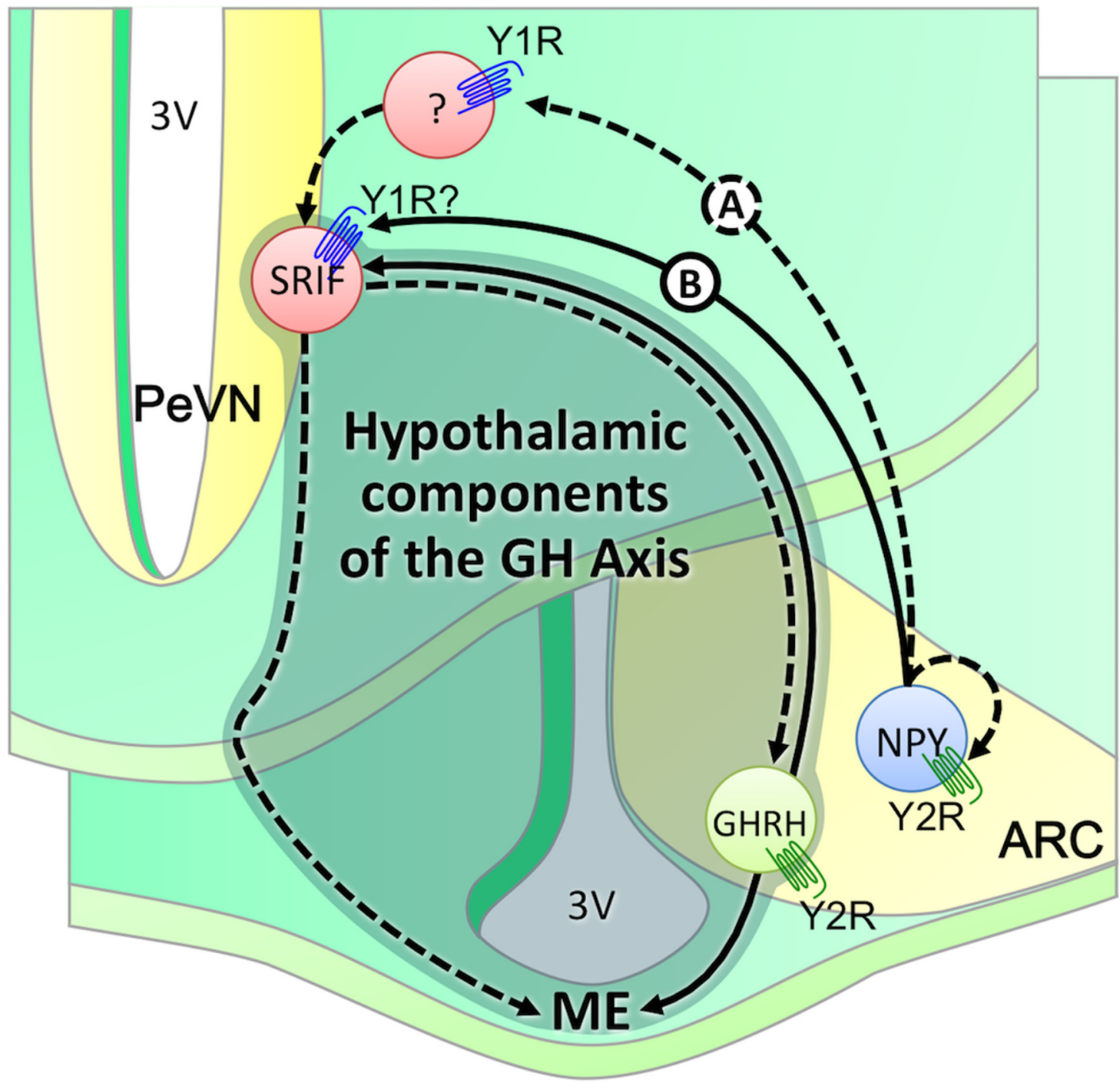

Figure 8. Schematicrepresentation defining interactions between hypothalamic components of the GH axis (shaded), NPY neurons, and Y-receptors. Fasting induces the activation of NPY neurons in the ARC. Current and published observations suggest that altered NPY activity promotes SRIF activity, presumably through activation of the postsynaptic Y1 receptors. Acting through intermediate inhibitory neurons, the Y1R may stimulate SRIF-ergic tone through withdrawal in inhibition (Scenario A). Alternatively, Y1R may directly modulate SRIF-egic tone via nonclassical G-protein-mediated pathways (Scenario B). In both scenarios, increased SRIF-ergic tone will inhibit GHRH-induced GH release, or directly inhibit somatotroph activity and thus GH release. Accordingly, GH release is not suppressed in fasting mice following germline deletion of NPY or Y1R. Under ad libitum-fed conditions, activation and/or inactivation of NPY neurons in the ARC are under tight control of Y2 receptors. Deletion of Y2 receptors results in impaired peak GH release, presumably through a potential increase in NPY feedback to SRIF neurons resulting in an increase in SRIF-ergic tone. Of interest, GHRH neurons express the Y2R (Lin et al., 2007) and promote GHRH activity (Osterstock et al., 2010). Thus, germline loss of Y2R may directly impact GHRH activity in ad libitum-fed mice, and thus GHRH-mediated GH release. PVN, paraventricular nucleus; 3 V, third ventricle; ME, medium eminence. Dashed lines represent an inhibitory effect whereas solid lines represent a stimulatory effect.

regulates bone formation (Baldock et al., 2002), the Y2R may also facilitate pubertal growth by sustaining optimal GH release.

The Y2R inhibits NPY release (Chen and van den Pol, 1996; Broberger et al., 1997) and deletion of Y2R increases hypothalamic Npy mRNA expression (Sainsbury et al., 2002). Consequently, the suppression of GH secretion in ad libitum-fed $Y 2 R^{-/-}$mice may occur in response to increased hypothalamic NPY activity. Given observed interactions between NPY and SRIF neurons, we predict increased inhibitory SRIF tone and thus $\mathrm{GH}$ release. The Y2R is expressed on GHRH neurons (Lin et al., 2007), and $Y 2 R$ agonist increases the discharge rate of GHRH neurons (Osterstock et al., 2010). Thus the loss of Y2R may contribute to altered GHRH tone, resulting in reduced-fed GH release. This requires further validation.

The differential effects of Y2R and NPY deletion on GH release suggest that factors other than NPY may modulate Y2R- mediated GH release, such as PYY, which activates the Y2R (Batterham et al., 2002). We anticipate that postprandial fluctuations in PYY secretion may underlie the selective role of Y2R in $\mathrm{GH}$ release in ad libitum-fed mice. This was somewhat corroborated by PYY data in fasting mice, as circulating PYY levels did not change during the fasting period. It is thus unlikely that PYY contributes to the loss of GH release at this time. In pigs, PYY3-36 (a potent agonist for Y2R; Dumont et al., 1994) treatment stimulates GH release following an overnight fast (Ito et al., 2006). As PYY expression rises in response to food intake (Batterham et al., 2002), PYY may signal the hypothalamus to sustain optimal GH release under fed conditions. Whether PYY modulates GH release, and whether these actions are mediated selectively via Y2R expression on GHRH, needs further assessment. Regardless, observations highlight a critical role for the Y2R (and potentially other Y-receptors) in growth and development. These complex in- 
teractions require extensive investigation, including the detailed assessment of peak pulsatile GH release in fed and fasting states.

Our observations demonstrate that NPY neurons represent a key hypothalamic node that integrates the production and release of GH relative to food intake. We propose that NPY neurons modify SRIF activity to suppress GH release in mice during fasting (Fig. 8). While the exact mechanism is not defined, these actions are likely mediated via postsynaptic Y1Rs acting via an intermediate neuron, or directly via SRIF neurons. We confirmed that the Y2R does not contribute to altered GH release in fasting mice. Rather, the Y2R sustains peak pulsatile GH output specifically in ad libitum-fed mice, potentially in response to peripheral factors released in response to feeding. Current observations are limited to germline knock-out animals, and thus cannot account for the existence of compensatory pathways that develop in the absence of NPY, Y1R, or Y2R signaling. Confirmation of detailed circuitry requires further assessment of $\mathrm{GH}$ release following selective alteration of hypothalamic NPY neuron activity, or Y1R and Y2R expression. Our data provide exciting evidence to confirm that the release of $\mathrm{GH}$ is tightly coupled to hypothalamic food intake mechanisms that mediate orexigenic responses.

\section{References}

Adams EF, Venetikou MS, Woods CA, Lacoumenta S, Burrin JM (1987) Neuropeptide Y directly inhibits growth hormone secretion by human pituitary somatotropic tumours. Acta Endocrinol 115:149-154. Medline

Attanasio AF, Shalet SM (2007) Growth hormone and the transition from puberty into adulthood. Endocrinol Metab Clin North Am 36:187-201. CrossRef Medline

Balasubramaniam A, Joshi R, Su C, Friend LA, James JH (2007) Neuropeptide Y (NPY) Y2 receptor-selective agonist inhibits food intake and promotes fat metabolism in mice: combined anorectic effects of Y2 and Y4 receptor-selective agonists. Peptides 28:235-240. CrossRef Medline

Baldock PA, Sainsbury A, Couzens M, Enriquez RF, Thomas GP, Gardiner EM, Herzog H (2002) Hypothalamic Y2 receptors regulate bone formation. J Clin Invest 109:915-921. CrossRef Medline

Batterham RL, Cowley MA, Small CJ, Herzog H, Cohen MA, Dakin CL, Wren AM, Brynes AE, Low MJ, Ghatei MA, Cone RD, Bloom SR (2002) Gut hormone PYY3-36 physiologically inhibits food intake. Nature 418:650654. CrossRef Medline

Becskei C, Lutz TA, Riediger T (2009) Diet-derived nutrients mediate the inhibition of hypothalamic NPY neurons in the arcuate nucleus of mice during refeeding. Am J Physiol Regul Integr Comp Physiol 297:R100R110. CrossRef Medline

Broberger C, Landry M, Wong H, Walsh JN, Hökfelt T (1997) Subtypes Y1 and Y2 of the neuropeptide $\mathrm{Y}$ receptor are respectively expressed in pro-opiomelanocortin- and neuropeptide-Y-containing neurons of the rat hypothalamic arcuate nucleus. Neuroendocrinology 66:393-408. CrossRef Medline

Bruno JF, Song J, Xu Y, Berelowitz M (1993) Regulation of hypothalamic preprogrowth hormone-releasing factor messenger ribonucleic acid expression in food-deprived rats: a role for histaminergic neurotransmission. Endocrinology 133:1377-1381. CrossRef Medline

Buckley K, Kelly RB (1985) Identification of a transmembrane glycoprotein specific for secretory vesicles of neural and endocrine cells. J Cell Biol 100:1284-1294. CrossRef Medline

Chabot JG, Enjalbert A, Pelletier G, Dubois PM, Morel G (1988) Evidence for a direct action of neuropeptide $\mathrm{Y}$ in the rat pituitary gland. Neuroendocrinology 47:511-517. CrossRef Medline

Chen G, van den Pol AN (1996) Multiple NPY receptors coexist in pre- and postsynaptic sites: inhibition of GABA release in isolated self-innervating SCN neurons. J Neurosci 16:7711-7724. Medline

Claret M, Smith MA, Batterham RL, Selman C, Choudhury AI, Fryer LG, Clements M, Al-Qassab H, Heffron H, Xu AW, Speakman JR, Barsh GS, Viollet B, Vaulont S, Ashford ML, Carling D, Withers DJ (2007) AMPK is essential for energy homeostasis regulation and glucose sensing by POMC and AgRP neurons. J Clin Invest 117:2325-2336. CrossRef Medline

Colmers WF, Bleakman D (1994) Effects of neuropeptide Y on the electrical properties of neurons. Trends Neurosci 17:373-379. CrossRef Medline

Cornford AS, Barkan AL, Horowitz JF (2011) Rapid suppression of growth hormone concentration by overeating: potential mediation by hyperinsulinemia. J Clin Endocrinol Metab 96:824-830. CrossRef Medline

Dumont Y, Cadieux A, Pheng LH, Fournier A, St-Pierre S, Quirion R (1994) Peptide YY derivatives as selective neuropeptide Y/peptide YY Y1 and Y2 agonists devoided of activity for the $\mathrm{Y} 3$ receptor sub-type. Brain Res Mol Brain Res 26:320-324. CrossRef Medline

Fetissov SO, Kopp J, Hökfelt T (2004) Distribution of NPY receptors in the hypothalamus. Neuropeptides 38:175-188. CrossRef Medline

Frohman LA, Downs TR, Chomczynski P (1992) Regulation of growthhormone secretion. Front Neuroendocrinol 13:344-405. Medline

Glad CA, Kitchen EE, Russ GC, Harris SM, Davies JS, Gevers EF, Gabrielsson BG, Wells T (2011) Reverse feeding suppresses the activity of the GH axis in rats and induces a preobesogenic state. Endocrinology 152:869882. CrossRef Medline

Hansel DE, Eipper BA, Ronnett GV (2001) Neuropeptide Y functions as a neuroproliferative factor. Nature 410:940-944. CrossRef Medline

Herzog H (2003) Neuropeptide Y and energy homeostasis: insights from Y receptor knock-out models. Eur J Pharmacol 480:21-29. CrossRef Medline

Hisano S, Tsuruo Y, Kagotani Y, Daikoku S, Chihara K (1990) Immunohistochemical evidence for synaptic connections between neuropeptide Y-containing axons and periventricular somatostatin neurons in the anterior hypothalamus in rats. Brain Res 520:170-177. CrossRef Medline

Howell OW, Scharfman HE, Herzog H, Sundstrom LE, Beck-Sickinger A, Gray WP (2003) Neuropeptide Y is neuroproliferative for post-natal hippocampal precursor cells. J Neurochem 86:646-659. CrossRef Medline

Howell OW, Doyle K, Goodman JH, Scharfman HE, Herzog H, Pringle A, BeckSickinger AG, Gray WP (2005) Neuropeptide Y stimulates neuronal precursor proliferation in the post-natal and adult dentate gyrus. J Neurochem 93:560-570. CrossRef Medline

Huang L, Steyn FJ, Tan HY, Xie TY, Veldhuis JD, Ngo ST, Chen C (2012) The decline in pulsatile GH secretion throughout early adulthood in mice is exacerbated by dietary-induced weight gain. Endocrinology 153:43804388. CrossRef Medline

Ito T, Thidarmyint H, Murata T, Inoue H, Neyra RM, Kuwayama H (2006) Effects of peripheral administration of PYY3-36 on feed intake and plasma acyl-ghrelin levels in pigs. J Endocrinol 191:113-119. CrossRef Medline

Karl T, Duffy L, Herzog H (2008) Behavioural profile of a new mouse model for NPY deficiency. Eur J Neurosci 28:173-180. CrossRef Medline

Kawano H, Daikoku S (1988) Somatostatin-containing neuron systems in the rat hypothalamus: retrograde tracing and immunohistochemical studies. J Comp Neurol 271:293-299. CrossRef Medline

Keen-Rhinehart E, Bartness TJ (2007) NPY Y1 receptor is involved in ghrelin- and fasting-induced increases in foraging, food hoarding, and food intake. Am J Physiol Regul Integr Comp Physiol 292:R1728-R1737. CrossRef Medline

Kishi T, Aschkenasi CJ, Choi BJ, Lopez ME, Lee CE, Liu H, Hollenberg AN, Friedman JM, Elmquist JK (2005) Neuropeptide Y Y1 receptor mRNA in rodent brain: distribution and colocalization with melanocortin-4 receptor. J Comp Neurol 482:217-243. CrossRef Medline

Klenke U, Constantin S, Wray S (2010) Neuropeptide Y directly inhibits neuronal activity in a subpopulation of gonadotropin-releasing hormone-1 neurons via $\mathrm{Y} 1$ receptors. Endocrinology 151:2736-2746. CrossRef Medline

Kohsaka A, Laposky AD, Ramsey KM, Estrada C, Joshu C, Kobayashi Y, Turek FW, Bass J (2007) High-fat diet disrupts behavioral and molecular circadian rhythms in mice. Cell Metab 6:414-421. CrossRef Medline

Lin S, Lin EJ, Boey D, Lee NJ, Slack K, During MJ, Sainsbury A, Herzog H (2007) Fasting inhibits the growth and reproductive axes via distinct $\mathrm{Y} 2$ and $\mathrm{Y} 4$ receptormediated pathways. Endocrinology 148:2056-2065. CrossRef Medline

Luque RM, Kineman RD (2006) Impact of obesity on the growth hormone axis: evidence for a direct inhibitory effect of hyperinsulinemia on pituitary function. Endocrinology 147:2754-2763. CrossRef Medline

Minami S, Kamegai J, Sugihara H, Suzuki N, Higuchi H, Wakabayashi I (1995) Central glucoprivation evoked by administration of 2-deoxy-Dglucose induces expression of the c-fos gene in a subpopulation of neuropeptide $\mathrm{Y}$ neurons in the rat hypothalamus. Brain Res Mol Brain Res 33:305-310. CrossRef Medline

Minami S, Kamegai J, Sugihara H, Suzuki N, Wakabayashi I (1998) Growth hormone inhibits its own secretion by acting on the hypothalamus through its receptors on neuropeptide Y neurons in the arcuate nucleus and somatostatin neurons in the periventricular nucleus. Endocr J 45: S19-S26. CrossRef Medline

Murphy BA, Fioramonti X, Jochnowitz N, Fakira K, Gagen K, Contie S, Lorsignol A, Penicaud L, Martin WJ, Routh VH (2009) Fasting en- 
hances the response of arcuate neuropeptide Y-glucose-inhibited neurons to decreased extracellular glucose. Am J Physiol Cell Physiol 296: C746-C756. CrossRef Medline

Ortiz AA, Milardo LF, DeCarr LB, Buckholz TM, Mays MR, Claus TH, Livingston JN, Mahle CD, Lumb KJ (2007) A novel long-acting selective neuropeptide $\mathrm{Y} 2$ receptor polyethylene glycol-conjugated peptide agonist reduces food intake and body weight and improves glucose metabolism in rodents. J Pharmacol Exp Ther 323:692-700. CrossRef Medline

Osterstock G, Escobar P, Mitutsova V, Gouty-Colomer LA, Fontanaud P, Molino F, Fehrentz JA, Carmignac D, Martinez J, Guerineau NC, Robinson IC, Mollard P, Méry PF (2010) Ghrelin stimulation of growth hormone-releasing hormone neurons is direct in the arcuate nucleus. PLoS One 5:e9159. CrossRef Medline

Pedragosa-Badia X, Stichel J, Beck-Sickinger AG (2013) Neuropeptide Y receptors: how to get subtype selectivity. Front Endocrinol 4:5. CrossRef Medline

Pierroz DD, Catzeflis C, Aebi AC, Rivier JE, Aubert ML (1996) Chronic administration of neuropeptide $\mathrm{Y}$ into the lateral ventricle inhibits both the pituitary-testicular axis and growth hormone and insulin-like growth factor I secretion in intact adult male rats. Endocrinology 137:3-12. CrossRef Medline

Raposinho PD, Pierroz DD, Broqua P, White RB, Pedrazzini T, Aubert ML (2001) Chronic administration of neuropeptide Y into the lateral ventricle of C57BL/6J male mice produces an obesity syndrome including hyperphagia, hyperleptinemia, insulin resistance, and hypogonadism. Mol Cell Endocrinol 185:195-204. CrossRef Medline

Rettori V, Milenkovic L, Aguila MC, McCann SM (1990) Physiologically significant effect of neuropeptide-y to suppress growth-hormone release by stimulating somatostatin discharge. Endocrinology 126:2296-2301. CrossRef Medline

Sainsbury A, Schwarzer C, Couzens M, Fetissov S, Furtinger S, Jenkins A, Cox HM, Sperk G, Hökfelt T, Herzog H (2002) Important role of hypothalamic Y2 receptors in body weight regulation revealed in conditional knockout mice. Proc Natl Acad Sci U S A 99:8938-8943. CrossRef Medline

Stanley S, Domingos AI, Kelly L, Garfield A, Damanpour S, Heisler L, Friedman J (2013) Profiling of glucose-sensing neurons reveals that GHRH neurons are activated by hypoglycemia. Cell Metab 18:596-607. CrossRef Medline

Steyn FJ, Huang L, Ngo ST, Leong JW, Tan HY, Xie TY, Parlow AF, Veldhuis
JD, Waters MJ, Chen C (2011) Development of a method for the determination of pulsatile growth hormone secretion in mice. Endocrinology 152:3165-3171. CrossRef Medline

Steyn FJ, Leong JW, Huang L, Tan HY, Xie TY, Nelson C, Waters MJ, Veldhuis JD, Epelbaum J, Chen C (2012) GH does not modulate the early fasting-induced release of free fatty acids in mice. Endocrinology 153: 273-282. CrossRef Medline

Suzuki N, Okada K, MinamiS, Wakabayashi I (1996) Inhibitory effect of neuropeptide $\mathrm{Y}$ on growth hormone secretion in rats is mediated by both Y1- and Y2receptor subtypes and abolished after anterolateral deafferentation of the medial basal hypothalamus. Regul Pept 65:145-151. CrossRef Medline

Tan HY, Huang L, Simmons D, Veldhuis JD, Steyn FJ, Chen C (2013) Hypothalamic distribution of somatostatin mRNA expressing neurones relative to pubertal and adult changes in pulsatile growth hormone secretion in mice. J Neuroendocrinol 25:910-919. CrossRef Medline

Tannenbaum GS, Epelbaum J, Videau C, Dubuis JM (1996) Sex-related alterations in hypothalamic growth hormone-releasing hormone mRNAbut not somatostatin mRNA-expressing cells in genetically obese Zucker rats. Neuroendocrinology 64:186-193. CrossRef Medline

Veldhuis JD, Johnson ML, Veldhuis OL, Straume M, Pincus SM (2001) Impact of pulsatility on the ensemble orderliness (approximate entropy) of neurohormone secretion. Am J Physiol Regul Integr Comp Physiol 281: R1975-R1985. Medline

Wu Q, Lemus MB, Stark R, Bayliss JA, Reichenbach A, Lockie SH, Andrews ZB (2014) The temporal pattern of cfos activation in hypothalamic, cortical, and brainstem nuclei in response to fasting and refeeding in male mice. Endocrinology 155:840-853. CrossRef Medline

Zhang X, Tong YG, Bao L, Hökfelt T (1999) The neuropeptide Y Y1 receptor is a somatic receptor on dorsal root ganglion neurons and a postsynaptic receptor on somatostatin dorsal horn neurons. Eur J Neurosci 11:22112225. CrossRef Medline

Zukowska-Grojec Z, Karwatowska-Prokopczuk E, Rose W, Rone J, Movafagh S, Ji H, Yeh Y, Chen WT, Kleinman HK, Grouzmann E, Grant DS (1998) Neuropeptide $Y$ : a novel angiogenic factor from the sympathetic nerves and endothelium. Circ Res 83:187-195. CrossRef Medline 